\title{
AKTIVITAS ANTIBAKTERI FRAKSI SAPONIN DARI KULIT BATANG TUMBUHAN KASTURI (Mangifera casturi)
}

\author{
K.Rosyidah $^{1}$, S.A.Nurmuhaimina ${ }^{1}$, N.Komari ${ }^{1}$, dan M.D.Astuti ${ }^{1}$ \\ ${ }^{1}$ Program Studi Kimia FMIPA Universitas Lambung Mangkurat, \\ Jl. A. Yani KM 36,0 Banjarbaru, 70714
}

\begin{abstract}
ABSTRAK
Penelitian ini bertujuan untuk mengetahui aktivitas antibakteri fraksi saponin kulit batang tumbuhan kasturi terhadap pertumbuhan bakteri E.coli dan S.aureus. Serbuk kulit batang kasturi $(512,67 \mathrm{~g})$ dimaserasi dengan metanol. Ekstrak metanol (32,57 g) dipartisi dengan n-heksana, diperoleh 5,98 gram ekstrak saponin. Ekstrak saponin difraksinasi dengan kromatografi vakum cair (KVC) menghasilkan 39 fraksi. Fraksi dengan Rf sama pada KLT digabung sehingga diperoleh empat fraksi A-D. Tiap-tiap fraksi diuji aktivitas antibakterinya terhadap bakteri E. coli dan S. aureus dengan metode difusi. Fraksi A paling aktif antibakteri dibandingkan tiga fraksi lainnya dengan diameter hambat sebesar 10,3 $\pm 0,5 \mathrm{~mm}$ terhadap bakteri E.coli dan 10,8 $\pm 0,3 \mathrm{~mm}$ terhadap S.aureus.
\end{abstract}

Kata kunci: Antibakteri, Kasturi, Mangifera casturi, saponin,

\begin{abstract}
This research to study antibacterial activity (E.coli and S.aureus) of saponin fractions from stem bark of Mangifera casturi. Powdered of stem bark of M.casturi $(512,67 \mathrm{~g})$ were extracted with methanol. Methanol extract (32.57 g) was partitionated with $n$-hexane to give saponin extract. Saponin extract (5.98 g) was partitionated by Vacuum Liquid Chromatography (VLC) over silica gel to give 39 fractions were grouped into four major fractions $A-D$ by combining fractions with similar TLC profile. Every fractions studied antibacterial activity with E. coli and S. Aureus with difusi methode. Fraction A most active then other fraction with inhibition diameter $10.3 \pm 0.5 \mathrm{~mm}$ (E.coli) and $10.8 \pm 0.3 \mathrm{~mm}$ (S.aureus).
\end{abstract}

Keywords: kasturi, Mangifera casturi, saponin, antibacteri.

\section{PENDAHULUAN}

Tumbuhan kasturi (Mangifera casturi) atau mangga kalimantan menarik untuk diteliti karena tumbuhan ini merupakan tumbuhan khas Kalimantan Selatan dan termasuk tumbuhan langka. Tumbuhan kasturi tersebar di daerah Kalimantan Selatan seperti Banjarbaru, Martapura, Kandangan, dan Tanjung. Selain itu tersebar juga di daerah Kalimantan Tengah dan Kalimantan Timur seperti Kutai dan Tenggarong Sebrang. Dilihat dari ekologinya tumbuhan ini hidup di daerah rawa. Buahnya menyerupai mangga kecil dan agak padat, baunya tajam dan rasanya khas. Kulitnya tipis, licin, hijau mengkilat dengan noda gelap (Kostermans \& Bompard, 1993).

Tumbuhan dari genus Mangifera yang sudah diteliti kandungan kimianya adalah Mangifera indica atau yang dikenal dengan sebutan mangga. Hasil penelitian tersebut menyebutkan bahwa M.indica mengandung flavonoid, terpenoid, saponin, tanin (Depkes, 2007), dan turunan alkilfenol (Knödler, et al., 2008). Ekstrak kulit batang Mangifera indica menunjukkan aktivitas antioksidan, antiinflamasi, dan mempunyai efek imunomodulator dengan sifat racun yang rendah sampai $2000 \mathrm{mg} / \mathrm{kg}$ berat badan (Gonzalez et al., 2007) serta aktif melindungi sel $\mathrm{T}$ dari AICD secara in vitro (Hernandez et al., 2007). Tumbuhan lainnya yang termasuk dalam genus Mangifera tetapi masih belum diteliti lebih lanjut adalah tumbuhan kasturi (Mangifera casturi).

Uji fitokimia pendahuluan dari tanaman kasturi yang dilakukan Mustikasari dan Ariyani (2007) mengindikasikan bahwa batang kasturi mengandung senyawa terpenoid, steroid, dan saponin. Beberapa hasil penelitian menunjukkan bahwa senyawa terpenoid 
(Gunawan, 2008), steroid (Islam, et al., 2003), dan saponin (Prihatman, 2001) mempunyai aktivitas sebagai antibakteri.

Suatu antibakteri adalah senyawa yang dapat menghambat pertumbuhan bakteri tertentu. Bakteri tersebut dapat menyebabkan timbulnya penyakit tertentu misalnya Escherichia coli yang merupakan penyebab diare dan Staphyloccocus aureus sebagai penyebab penyakit kulit. Menurut Jones (2004) penyakit yang disebabkan oleh bakteri seperti diare dapat menyebabkan kematian sekitar tiga juta penduduk setiap tahun sehingga diperlukan pengobatan secara intensif terhadap diare. Makalah ini memaparkan tentang kemampuan fraksi saponin tumbuhan kasturi sebagai antibakteri.

\section{METODE PENELITIAN}

Bahan Penelitian. Bahan-bahan yang digunakan adalah kulit batang kasturi, pelarut organik yang mempunyai kualitas teknis seperti $\mathrm{CH}_{3} \mathrm{OH}$ (metanol), $\mathrm{CH}_{3}\left(\mathrm{CH}_{2}\right)_{4} \mathrm{CH}_{3}$ (n-heksana), $\mathrm{CH}_{3} \mathrm{COOC}_{2} \mathrm{H}_{5}$ (etil asetat) dan $\mathrm{CH}_{2} \mathrm{Cl}_{2}$ (metilen klorida), pelarut organik yang mempunyai kualitas p.a yaitu $\mathrm{CHCl}_{3}$ (E.Merck), $\mathrm{H}_{2} \mathrm{SO}_{4}$ pekat $(97 \%$, bj 1,84 kg/l), silika gel G60 (E.Merck), silika gel $\mathrm{GF}_{254}$ (E.Merck), plat KLT alumunium berlapis Kieselgel $\mathrm{GF}_{254}$ setebal 0,25 mm (E.Merck), akuades, media nutrient broth (NB) (E.Merck), nutrient agar (NA) (E.Merck), biakan E. coli, biakan $S$. aureus, paper disk dengan diameter $6 \mathrm{~mm}$, dan tetrasiklin.

Persiapan Sampel. Sampel berupa kulit batang tumbuhan kasturi dikumpulkan, dicuci dan dikeringkan di udara terbuka. Sampel yang sudah kering dibuat menjadi potongan kecil lalu dihaluskan dengan blender.

Ekstraksi. Sebanyak 500 gram serbuk kulit batang tumbuhan kasturi dimaserasi dengan 10L metanol sebanyak 2 kali selama 24 jam. Selanjutnya disaring, filtratnya dipekatkan dengan rotary vaccum evaporator hingga diperoleh ekstrak metanol kering.

Partisi. Ekstrak metanol kering dilarutkan dalam metanol kemudian dipartisi dengan $n$-heksana dalam corong pisah sehingga terbentuk busa stabil. Busa yang stabil dipekatkan dengan penguap putar sampai kering sehingga diperoleh ekstrak saponin padat.

Fraksinasi. Ekstrak saponin padat diimpregnasi menggunakan silika gel 60 kemudian dimasukkan ke dalam kolom KVC. Kolom dielusi dengan pelarut kloroform:aseton (7:3). Eluat yang dihasilkan dari proses elusi ditampung dalam wadah terpisah sehingga menghasilkan sejumlah fraksi. Fraksi yang harga Rf nya sama digabungkan sehingga diperoleh beberapa fraksi gabungan. Setiap fraksi gabungan diuji aktivitas antibakterinya.

Uji aktivitas antibakteri. Metode yang digunakan metode difusi. Biakan bakteri yang sudah diremajakan terlebih dahulu dimasukkan ke dalam media Nutrien broth (NB) kemudian diinkubasi selama 24 jam. Sebanyak $0,1 \mathrm{ml}$ bakteri dalam NB dimasukkan ke dalam media NA yang telah disterilkan terlebih dahulu. Selanjutnya paper disk diameter $6 \mathrm{~mm}$ yang sudah berisi $2 \%(\mathrm{~b} / \mathrm{v})$ sampel tiap fraksi, $0,25 \%(\mathrm{~b} / \mathrm{v})$ tetrasiklin dan kontrol metanol diletakkan di atas NA. Cawan petri yang berisi media NA diinkubasi pada suhu $37{ }^{\circ} \mathrm{C}$ selama 24 jam kemudian diukur diameter hambatnya.

\section{HASIL DAN PEMBAHASAN}

\subsection{Persiapan Sampel}

Sebanyak 512,67 g serbuk batang kasturi dimaserasi dengan $10 \mathrm{~L}$ metanol selama 24 jam kemudian disaring (maserat I). Maserasi diulang dengan pelarut metanol yang baru, kemudian disaring (maserat II). Masert I berwarna coklat tua sedangkan maserat II berwarna coklat muda, hal ini menunjukkan bahwa metabolit sekunder yang ada pada sampel batang kasturi sudah banyak terekstrak. Pengulangan proses maserasi ini bertujuan agar seluruh senyawa metabolit sekunder dalam sampel larut dalam pelarut metanol. Maserat I dan II diuapkan dengan alat penguap putar bertekanan (rotary vacum evaporator) hingga diperoleh 32,57 g ekstrak metanol kering. 
ALCHEMY, Vol. 1 No. 2 Maret 2010, hal 53-103

\begin{tabular}{|c|l|c|c|}
\hline \multicolumn{3}{|c|}{ Tabel 1. Hasil uji aktivitas antibakteri dari tiap fraksi } \\
\cline { 3 - 4 } No & \multicolumn{2}{|c|}{ Kontrol } & \multicolumn{2}{|c|}{ Diameter hambatan zona bakteri (mm) } \\
\hline 1 & Fraksi A & E. coli & S. aureus \\
2 & Fraksi B & - & $10,8 \pm 0,5 \mathrm{~mm}$ \\
3 & Fraksi C & - & $10,3 \pm 0,2 \mathrm{~mm}$ \\
4 & Fraksi D & - & $10,1 \pm 0 \mathrm{~mm}$ \\
5 & Tetrasiklin & $20,6 \pm 0 \mathrm{~mm}$ & - \\
6 & Metanol & - & $30,6 \pm 0 \mathrm{~mm}$ \\
\end{tabular}

Ekstrak metanol yang diperoleh dilarutkan kembali dalam 100ml metanolkemudian dipartisi dengan $100 \mathrm{ml} n$ heksana dalam corong pisah. Campuran dikocok dan didiamkan sampai terbentuk lapisan yang memisah. Ketika dikocok ternyata terbentuk busa yang permanen dan tebal, ini menunjukkan bahwa fraksi metanol kaya akan senyawa saponin. Lapisan busa yang terbentuk dipisahkan dan dilakukan kembali partisi dengan $100 \mathrm{ml} n$-heksana terhadap fraksi metanol sisa, kemudian dikocok dan didiamkan. Busa stabil dipisahkan dan disatukan dengan hasil partisi pertama. Pengulangan partisi ini dimaksudkan agar senyawa metabolit sekunder larut $n$-heksana yang tertinggal di fraksi metanol sisa dapat terekstrak. Busa stabil yang dihasilkan dari proses partisi dipekatkan dengan rotary vacum evaporator sehingga diperoleh ekstrak saponin sebanyak 5,98 g.

\subsection{Fraksinasi}

Ekstrak saponin dipisahkan dengan kromatografi vakum cair (KVC) menggunakan 50,02 g silika gel dengan fase gerak kloroform dan aseton dengan polaritas meningkat. Eluat ditampung dalam botol dan diperoleh 39 fraksi. Fraksi-fraksi yang diperoleh dari KVC dipantau dengan KLT untuk mengetahui pola kromatogram dari masing-masing fraksi. Fraksi yang memiliki pola noda yang sama digabungkan dan diperoleh 4 fraksi gabungan yaitu fraksi A sebanyak 0,34 g, fraksi B sebanyak 1,22 g, fraksi $\mathrm{C}$ sebanyak 3,16 g dan fraksi D sebanyak $0,13 \mathrm{~g}$. masing-masing fraksi gabungan diuji aktivitas antibakterinya dengan metode difusi.

\subsection{Uji Aktivitas Antibakteri dengan Metode Difusi}

Uji aktivitas antibakteri fraksi gabungan dari ekstrak saponin batang tumbuhan kasturi bertujuan untuk mengetahui kemampuan fraksi-fraksi tersebut dalam menghambat pertumbuhan bakteri $E$. coli dan $S$. aureus. Kemampuan penghambatan ditandai dengan terbentuknya zona hambat (zona bening) di sekitar paper disk yang mengandung ekstrak saponin.

Menurut Pratama (2005), zona bening di sekitar kertas disk menunjukkan adanya aktivitas antibakteri. Luas zona bening itu sendiri sangat dipengaruhi oleh daya antibakteri fraksi tersebut. Hasil uji aktivitas antibakteri terhadap fraksi A, B, C dan D dapat dilihat pada Tabel 1 .

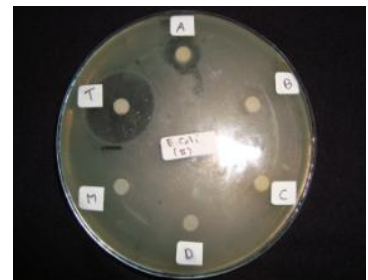

(a)

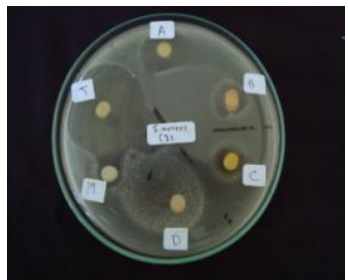

(b)
Gambar 1. Uji aktivitas terhadap E.coli (a) dan S.aureus (b), A=fraksi A, B=fraksi $\mathrm{B}, \mathrm{C}=$ fraksi $\mathrm{C}, \mathrm{D}=$ fraksi $\mathrm{D}$, $\mathrm{M}=$ metanol (kontrol negatif), $\mathrm{T}=$ tetrasiklin (kontrol positif)

Tabel 1 menunjukkan bahwa fraksi A memiliki aktivitas antibakteri yang paling besar karena memiliki luas zona hambat bakteri yang paling besar. Fraksi A merupakan fraksi paling non polar. Pada Tabel 1 hasil uji aktivitas antibakteri fraksi-fraksi menunjukkan bahwa 
aktivitas terhadap $S$. aureus lebih besar dibandingkan terhadap E. coli.

Menurut Pelczar et al., (1988) untuk dapat membunuh mikroorganisme, bahan uji harus masuk ke dalam sel melalui dinding sel. Kedua jenis mikroorganisme uji tersebut memiliki komposisi dinding sel yang berbeda. Dinding sel $S$. aureus yang merupakan kelompok bakteri Gram positif memiliki struktur dengan sedikit lipid sedang pada E.coli yang merupakan bakteri Gram negatif relatif lebih banyak mengandung lipid. Senyawa terpenoid mudah larut dalam lipid sifat inilah yang mengakibatkan senyawa ini lebih mudah menembus dinding sel bakteri Gram positif dan sel bakteri Gram negatif.

Menurut Jawetz et al., (2001) pertumbuhan bakteri yang terhambat atau kematian bakteri akibat adanya penghambatan terhadap sintesis protein. Mekanisme kerja tertrasiklin sebagai kontrol positif, yaitu menghambat sintesis protein dengan mencegah terikatnya tRNA di ribosom (Brooks et al., 2001), sehingga dapat dikatakan bahwa senyawa terpenoid, steroid dan saponin dapat menghambat pertumbuhan bakteri $S$. aureus dengan mekanisme penghambatan terhadap sintesis protein karena terakumulasi dan menyebabkan perubahan komponen-komponen penyusun sel bakteri itu sendiri.

Beberapa tumbuhan dari famili Anacardiaceae dilaporkan aktif antibakteri diantaranya ekstrak etanol biji Mangifera indica (Kabuki et al, 2000), senyawa etil gallat dari Mauria heterophylla (Anacardiaceae) bersifat antibakteri Escherichia coli 35992, Staphylococcus aureus 20213 dan Pseudomonas aeruginosa 15442 (Mori et al, 2006).

\section{KESIMPULAN}

Pertumbuhan bakteri $S$. aureus dan $E$. coli dapat dihambat dengan baik oleh fraksi A yang diperoleh dari ekstrak saponin pada kulit batang tumbuhan kasturi (Mangifera casturi) dengan diameter hambat sebesar 10,3 $\pm 0,5 \mathrm{~mm}$ terhadap bakteri E.coli dan 10,8 $\pm 0,3 \mathrm{~mm}$ terhadap S.aureus. .

\section{DAFTAR PUSTAKA}

Brooks, G.F., Butel, J.S. dan S.A Morse. 2001. Mikrobiologi Kedokteran. Terjemahan Bagian Mikrobiologi Fakultas Kedokteran Universitas Airlangga. Salemba Medika.Jakarta.

Depkes. 2007. Mangifera indica L. (diakses tanggal 20 Juli 2007)

http://www.warintek.ristek.go.id/pangan_keseh atan/tanamanobat/depkes

González, J.E., Rodriguez, M.D., Rodeiro, I., Morffi, J., Guerra, E., Leal, F., Garcia, H., Goicochea, E., Guerrero, S., Garrido, G., 2007. Food and Chemical Toxicology. in press.

Gunawan, IW.G., Gede, B.IW.A dan N.L Sutrisnayanti. 2008. Isolasi Dan Identifikasi Senyawa Terpenoid Yang Aktif Antibakteri Pada Herba Meniran (Phyllanthus niruri linn). Jurnal Kimia 2(1).Jurusan Kimia FMIPA Universitas Udayana, Bukit Jimbaran.

Hernandez, P., Rodriguez, P.C., Delgado, R., and Walczak, H. 2007. Pharmacological Research. 55. 167173

Islam, N.A.K.M., Abbas, A.M., Sayeed, A., Abdus Salam-Syed, M., Islam, A., Rahman, M., Mohal-Khan, A.M.G.R. dan S. Khatun. 2003. An Antimicrobial Terpenoid From Caesalpinia pulcherrima Swartz: Its Characterization, Antimicrobial and Cytotoxic Activities. Asian Journal of Plant Sciences 2 (17-24): 1162-1165

Jawetz, E., Melnick G.E. and C.A Adelberg. 2001. Mikrobiologi kedokteran. Edisi I. Diterjemahkan oleh Penerjemah Bagian Mikrobiologi Fakultas Kedokteran Universitas Airlangga. SalembaMedika. Surabaya.

Jones, A.C.C. dan M.J.G Farthing. 2004. Management of infectious diarrhoea. Gut. 53:296-305.

Kabuki, T., Nakajima, H., Arai, M., Ueda, S., Kuwabara, Y., Dosako, S.2000. Food Chemistry. 71. 61-63 
Kno“ dler, M., Ju“rgen Conrad , Eva M.

Wenzig, Rudolf Bauer, Markus Lacorn,

Uwe Beifuss, Reinhold Carle, Andreas

Schieber. 2008. Anti-inflammatory 5-

(110Z-heptadecenyl)- and 5-

(80Z,110Z-heptadecadienyl)-

resorcinols from mango (Mangifera

indica L.) peels. Phytochemistry. 69.

988-993

Kostermans, A.J.G.H \& J.M. Bompard. 1993.

The Mangoes. Their Botany,

Nomenclature, Horticulture and

Utilization. Academic Press Harcourt

Brace \& Company, London

Mori T, Chang C, Maurtua D, Hammond GB. 2006. Phytother Res., 20(2):160-161

Mustikasari, K. dan D. Ariyani. 2007. Skrining Metabolit Sekunder Pada Akar Binjai (Mangifera caesia) dan Kasturi (Mangifera casturi). Laporan Penelitian Dosen. FMIPA Universitas Lambung Mangkurat. Banjarbaru.

Pelczar, M. F, Pelczar M.J.Jr \& E. C. S. Chan. 1988. Dasar-Dasar Mikrobiologi Terjemahan Ratna S Hadioetomo, Teja Imas, S.Sutami, Tjitiosomo, Sri Lestari Angka. Universitas Indonesia (U I Press). Jakarta

Plantamor. 2007. Klasifikasi Mangga kasturi. http://www.plantamor.com/spcdtail.php ?recid=1762\&popname=Mangga $\% 20 \mathrm{ka}$ sturi. Diakses tanggal 27 april 2008

Pratama, M.R. 2005. Pengaruh Ekstrak Serbuk Kayu Siwak (Salvadora persica) Terhadap Pertumbuhan Bakteri Streptococcus mutans dan Staphylococcus aureus Dengan Metode Difusi Agar. Laporan Hasil Penelitian Program Studi Biologi. Fakultas Matematika Dan Ilmu Pengetahuan Alam Institut Teknologi Sepuluh Nopember.

Prihatman, K. 2001. Saponin Untuk Pembasmi Hama Udang. Laporan Hasil Penelitian. Pusat Penelitian Perkebunan Gambung. Bandung. 